
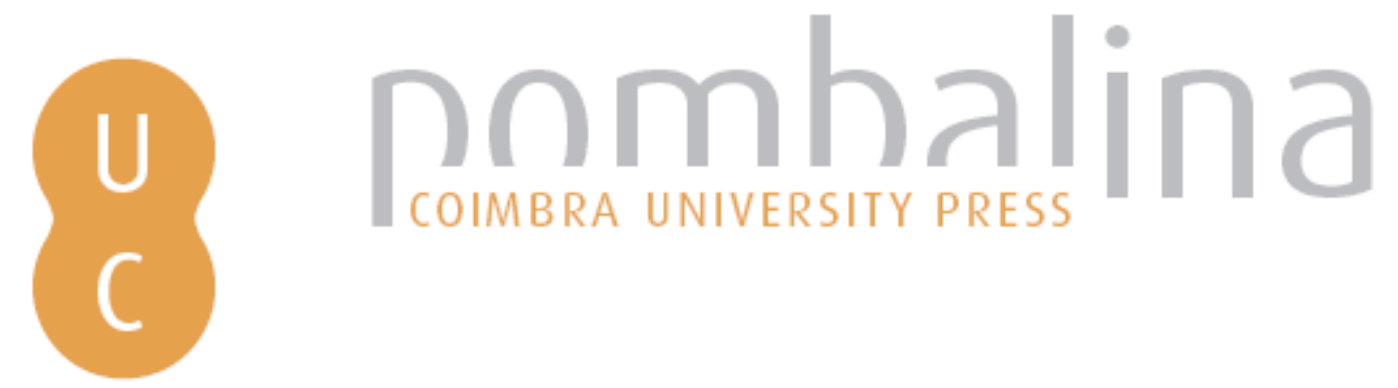

\title{
Bologna process and the rethinking of the role of higher education: teaching strategies focused on students' skills achievement
}
Autor(es):
Melo, Ana Souto e
Publicado por: Imprensa da Universidade de Coimbra
URL
persistente:
URI:http://hdl.handle.net/10316.2/46340
DOI:
DOI:https://doi.org/10.14195/978-989-26-1620-9_1
Accessed : $\quad$ 26-Apr-2023 13:27:21

A navegação consulta e descarregamento dos títulos inseridos nas Bibliotecas Digitais UC Digitalis, UC Pombalina e UC Impactum, pressupõem a aceitação plena e sem reservas dos Termos e Condições de Uso destas Bibliotecas Digitais, disponíveis em https://digitalis.uc.pt/pt-pt/termos.

Conforme exposto nos referidos Termos e Condições de Uso, o descarregamento de títulos de acesso restrito requer uma licença válida de autorização devendo o utilizador aceder ao(s) documento(s) a partir de um endereço de IP da instituição detentora da supramencionada licença.

Ao utilizador é apenas permitido o descarregamento para uso pessoal, pelo que o emprego do(s) título(s) descarregado(s) para outro fim, designadamente comercial, carece de autorização do respetivo autor ou editor da obra.

Na medida em que todas as obras da UC Digitalis se encontram protegidas pelo Código do Direito de Autor e Direitos Conexos e demais legislação aplicável, toda a cópia, parcial ou total, deste documento, nos casos em que é legalmente admitida, deverá conter ou fazer-se acompanhar por este aviso.

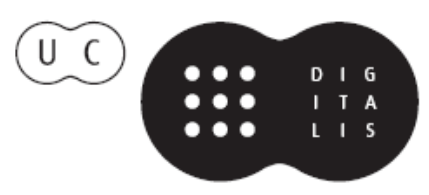


Cristina Pinto Albuquerque Ana Maria Seixas

Albertina Lima Oliveira

António Gomes Ferreira

Maria Paula Paixão

Rui Paquete Paixão COORDS

\section{HIGHER}

EDUCATION

AFTER

BOLOGNA

Challenges and Perspectives 


\title{
CHAPTER 1
}

\section{BOLOGNA PROCESS AND THE RETHINKING OF THE ROLE OF HIGHER EDUCATION: teaching strategies focused on students' skills achievement}

\author{
Ana Souto e Melo \\ CI\&DETS, Instituto Politécnico de Viseu (Portugal) \\ Email: anamelo@esev.ipv.pt
}

Emerging labour market training needs have foreseen a new educational paradigm, under the Bologna Process, based on skills development. This article aims to present the main results of a comparative case study on the impact of this process on a course taught in two Portuguese higher education institutions through the opinion of participants and analysis of institutional documents, highlighting, in particular, the valued skills in the current course. 


\section{Introduction}

The reformulation of the aims of Higher Education in the countries of the European Union (EU) has emerged as one of the main intentions of the Bologna Process in the face of the challenges and opportunities that emerge in a context of increasing global economic integration. One of its objectives was therefore to make the European area attractive, compatible and competitive (Bologna Declaration, 1999) and it is therefore essential to ensure training in the face of the difficulties inherent in a globalized society.

It is considered that the Magna Carta, signed by the Rectors of the European Universities in 1988 in Bologna, was in the genesis of the Bologna Process. This document refers to the university as being the focus that generates cultural, scientific and technological knowledge of society, thus giving it an important responsibility with regard to the economic and social development of the countries. The Bologna Process can be understood as arising from the European conjuncture, above all by the interest of the Member States in defining a common strategy, both politically and socially, with the ultimate aim of achieving higher levels of competence, productivity and competitiveness Relative to other countries in the world, namely the United States of America and Japan.

The approximation of Higher Education to the world of work requires the formation of properly qualified human resources, endowed with skills that are considered necessary for the technological, economic and cultural development of the current society. The role of universities in the production of intellectual knowledge in academic freedom, particularly those defended by the Humboldtian model (Neave, 1998), was replaced by the professional functions with the implementation of the 
Bologna Process (González \& Wagenaar, 2008; European, EACEA, \& Eurydice, 2015).In order for higher education institutions to adjust their training offer to market laws, the emergence of useful knowledge as a convergent support of the whole structuring and organization of knowledge and, consequently, of the respective training courses that, in this sense, are aligned with the compatibility of the educational dimensions with the demands of the labor market, giving shape to a new educational paradigm based on the development/acquisition of competences, as evidenced in one of the studies developed in the scope Tuning Project $^{1}$ (González \& Wagenaar, 2008).

The production of knowledge is no longer solely directed at the academic world, reconciling knowledge with its effective professional application, boosting productivity and competitiveness, highlighting the balance between the acquisition of specific and generic/transversal competences in the professional success of citizens. The higher order skills are considered, according to Lebrun (2008), essential in a quality training, since they will promote the acquisition of knowledge and key points in the Bologna Process, in learning to learn and in lifelong learning.

It is in this context that this research article is inserted, whose main objective is to reflect and disseminate the results obtained in a study on the impact of the Bologna Process on a master's degree course in teaching, taught at two Portuguese Higher Education institutions, patenting, in the first moment, the legal and historical framework of the challenges and opportunities brought about by the Bologna Process and the reflection on the

\footnotetext{
${ }^{1}$ It is an initiative working group of the European Commission within the framework of the Socrates and Tempus programs, which is of great relevance in assessing the impact of the Bologna Process on higher education institutions in the Member States.
} 
concept of competence within the same Process; in a second moment, we intend to highlight what the meaning attributed to the competence by the participants and what competences valued in the course under study.

\section{Main focus of the chapter}

The Bologna Process has had an extraordinary impact (European Commission, 2010), an aspect which we can foresee is still far from over. This is related to the persistent updating and adaptation of a system that has as main objective a greater articulation between the member states to reach their strategic objectives to face the increase of the levels of social, cultural and economic competitiveness in the European space. In fact, the objectives underlying the whole process have been adjusted over a period of approximately twenty years, since the practical realization of the innovation of the educational paradigm that has persisted for decades in our educational systems and which forms an integral part of a mentality rooted by all (both trainees and trainers) is a step that "may well take the time of a generation" (Feyo Azevedo, 2004, p. 1).

During this period, an effort has been made in reflection and discussion, as well as in the production of documents, which set out some of the fundamental principles in pursuing this path and political decision making in order to converge towards a common European dimension. Although results from more recent studies point to a clear cooperation and convergence of European Higher Education systems, there are still many difficulties underlying its actual implementation, which makes us consider the Bologna Process as a set of opportunities and challenges that only the persistent efforts of students, teachers 
and employers can guarantee their effective implementation in a continuous process of search, shared reflection, discovery and effective renewal of Higher Education systems. In other words, Bologna is a biggest challenge will be to fulfill the assumptions already outlined in the various meetings of the member states, namely the effective development of generic competences to specific ones, bringing with them the true scope of one of the most ambitious the objectives of the Bologna Process are the approximation of the knowledge developed in the scope of Higher Education to the current labor market needs, thus giving it the effective responsibility with regard to the economic and social development of the countries, which we intend to trigger with the present investigation.

\subsection{The Bologna Process: Opportunities and Challenges}

The Bologna Process has had a great impact and expansion which has not been limited only to the countries belonging to the EU. This aspect confirms a consolidated view of its success assumptions and, to that extent, also insists in its consequence several opportunities that highlight the renewal of Higher Education systems. In addition to the emerging opportunities, there are numerous challenges brought by the goal of a consolidation and convergence of enormous scope that has been considered as a process yet to be completed, but throughout its implementation has been shown to follow an evolutionary line and of conclusive realization. We come to reflect on the achievements and challenges of the various meetings of member states within the framework of the Bologna Process, taking into account more recent results on their implementation. 


\section{Cooperation and adequacy for competitiveness}

The main impact of the Bologna Process is that starting from a strategy of common interest and organization for the social, economic and cultural development of European countries, it acts as an incentive for Higher Education reforms, a unique opportunity for confronting and solving problems that affect the organization of Higher Education and that Bologna calls into question. In this sense, the Bologna Process has been affirmed as a generalized harmonization of the educational structures of Higher Education in Europe, translating itself into practice in the identical structural and organizational organization of the Higher Education systems, offering similar and comparable training courses, both in terms of contents and in terms of duration and conferring diplomas of equivalent value at both academic and professional levels (General Direction of Higher Education, 2008). In this way, we have adapted the various Higher Education systems through the cooperation and convergence of common strategic objectives linked to the transformations demanded by the new market economy (Sobrinho, 2005). This idea has its origin in the Magna Carta of the European Universities (1988) in which the protagonism of the universities was acknowledged as the main source of knowledge of the society and responsible for its cultural, scientific and technical development, with a well various meetings of the member states of the European Higher Education Area within the framework of the Bologna Process, which establish lines of action to be achieved by the year 2020 (Yerevan Declaration, 2015).

We are therefore faced with a functionalist conception of university (Dréze \& Debelle, 1983) in which Higher Education turns to social and economic needs in order to serve the Nation and in which it is considered as a fundamental instrument in vocational training of citizens emphasizing the utilitarian value of 
knowledge, reconciling educational dimensions with professional requirements. The fundamental objective of Higher Education is to provide students with knowledge based on market laws, defending the notion of useful knowledge as the unifying axis of all the structuring and organization of the courses, with the intention of curricula being Market needs measured through interinstitutional cooperation with employers.

Taking into account this necessary link between higher education systems with employers, the European Qualifications Framework for Lifelong Learning (EQF) and its National Qualifications Frameworks (NQF) are set up by Parliament and the European Council (2008, May 6), which reaffirmed the interest in a European Higher Education system based on the diversity of academic profiles for each cycle of studies, stating the corresponding competences and professional exits. The main objectives of these frameworks were to help member states, Higher Education institutions, employers and citizens compare the qualifications awarded by the different European education and training systems, as well as to understand the relevance of the qualifications to meet the needs of the labor market of each country. Its purpose is not only to determine the level of student learning but also to identify the country's needs in the labor market (European Commission, 2010).

According to the results of the most recent Implementation Report of the Bologna Process in the European Higher Education Area (European Commission, EACEA \& Eurydice, 2015) and with regard to the national qualifications system, it can be seen that in most of the participating countries there has been a growing correspondence between training cycles and levels of qualification stemming from the EQF. While some 15 countries in the European Higher Education Area have stated that they have not yet joined the EQF, some 32 countries (plus 10 countries over the year 
2012) have adapted the descriptions of the common framework to their specific characteristics and needs. The aforementioned report also states that only half of the NQF implemented include levels corresponding to all levels of education (from Elementary to Higher Education) and that the other half of the countries relate the NQF only to Higher Education, an aspect that in our view impedes the relationship between higher education and other levels of education, and on the other, prevents the accreditation of informal learning, which is often responsible for the acquisition and development of generic skills.

\section{Compatibility as a common qualification support for mobility}

Also in the scope of cross-border cooperation, one of the most outstanding aspects of the Bologna Process is the proposal to increase mobility in Higher Education and for this purpose it is advocated the generalization of a credit system with the implementation of the European Credit Transfer and Accumulation System (ECTS) in order to ensure greater transparency and ease of understanding and recognition of the academic equivalence of learning outcomes among several higher education institutions. This academic recognition promotes a more open European area, which in turn stimulates student mobility, both between institutions of the countries themselves, regions and cities, and between institutions in different countries, a matter evidently defended in several meetings held in the Bologna Declaration (1999), Prague Declaration (2001), Salamanca Declaration (2001), and Helsinki Seminar (2001).

Recent results show that the majority of the countries of the European Higher Education Area, around 80\%, followed the said pattern of ECTS award, with around seven countries allocating ECTS based on a combination of student work (hours 
of autonomous work) with the teacher's work (contact hours) (European Commission, EACEA \& Eurydice, 2015). Portugal is one of those cases, where the number of hours allocated for self-employment and for contact respectively is sometimes made casually and taking into account the nature of the course. In addition, about $19 \%$ of the member states do not guarantee that the allocation between the number of ECTS, the learning outcomes and the defined evaluation criteria has been achieved. According to the same report, this combination of credits based on the student's learning outcomes and workload is not reconcilable with the ECTS system, since it undermines the desired objectivity in the compatibility of training and qualifications between the various systems and demonstrates the persistent difficulty in implementing mobility. In addition to this obstacle to mobility, more than half of the higher education institutions do not yet have a well-established mobility strategy and their funding remains the main obstacle to their implementation, with only a minority of about 5\% of students from the European Higher Education Area, benefits from this experience (European Commission, EACEA \& Eurydice, 2015), data demonstrating that mobility is still a purpose to be achieved in the future.

\section{European strategy for the development of the knowledge-based society}

Another challenge brought by Bologna Process was the idea that research is an irreplaceable factor for social and human growth in order to face increasing competitiveness (Barcelona Declaration, 2002; Magna Carta of the European Universities, 1988). The dynamization of the knowledge society was one of the dimensions evidenced as being strictly necessary for the pursuit of the objectives outlined for the implementation of the Bologna 
Process which resulted in the implementation of the European Research Area. In this regard, we can see that, over the last fifty years, we have been witnessing an increase in the production of knowledge incomparably superior to any other period in the history of mankind, more oriented towards the practical application of it (Sobrinho, 2005). In the Leuven (2009) and Bucharest (2012) Declarations the idea was expressed that research should be closely linked to teaching and learning, addressing the problems of today's society through the production of practical solutions to solve them and reaffirming its strengthening as a necessary precondition for the consolidation of the European Higher Education Area. Later, the Yerevan Declaration (2015) establishes research as a priority for action to be achieved by the year 2020 .

Despite this desire to strengthen research in higher education systems, there is a lack of investment in most EU countries, particularly in Portugal. Only countries such as Finland, Sweden or Denmark have an investment in research of more than $3 \%$ of GDP (Ferreira, Silva, \& Firmino, 2014). On the one hand, Bologna argues that one should invest in research; on the other hand, the funding of higher education institutions is reduced so that they can make such an investment. In fact, in Portugal, from year to year, the number of research fellowships decreases and the hours of research or research accompaniment are no longer counted as teaching time, difficulties that must be reconsidered along with the financial autonomy of the institutions Higher Education, since they clearly hamper the achievement of the aforementioned objective.

\section{Quality and certification assurance}

Quality assurance for the professional qualification of citizens is also one of the most ambitious challenges laid down by 
the Bologna Process. In most European university systems, a relevant tradition of autonomy persisted, which in some cases resulted in the absence of external monitoring and certification mechanisms for the courses taught and, in other cases, the lack of implementation of forms of academic quality control government inspection. However, this is a situation that is being changed with great agility, by the growing consolidation of the European Community process and the consequent demand for the economic and cultural integration of Europe, through which the adoption of forms of academic quality assurance and systems external evaluation and accreditation. The purpose of this action was, on the one hand, quality assurance and recognition based on comparable data; on the other hand, the establishment of adequate indicators to describe the different profiles of Higher Education, institutions and study programs (Berlin Declaration, 2003; Leuven Declaration, 2009; Prague Declaration, 2001; Salamanca Declaration, 2001).

The European Association for Quality Assurance in Higher Education (ENQA) has played an important role in promoting European cooperation for quality assurance in higher education, bringing together the main government and private accreditation bodies of all EU countries, thus providing forms of dialogue and interaction between the various agencies involved. The purpose of this action was to create a set of measures, procedures and guidelines related to quality certification, to establish a common frame of reference, to test systems suitable for quality certification (agencies or institutions) and to disseminate good evaluation practices.

As the Report on the impact of the Bologna Process on the European Higher Education Area demonstrates, quality assurance in Higher Education is in full expansion and dynamism, recognizing that the Bologna Process and the consequent development of the 
European Area of Education have contributed significantly to this expansion. However, the question is whether quality assurance is achieving the desired results and, in this field, there is a growing awareness that there is still a lot of progress to be made, studentcentered learning. In the above mentioned Report, regarding student participation, no positive evidence was found, that is, as systems are reorganized, there is a prospect of a decrease in student participation, which is not desirable since In Bologna the student is an intervening part of the whole formative process (European Commission, EACEA \& Eurydice, 2015). The effective participation of the student in the evaluation systems is still a challenge to be concretized. Further progress is being made towards the possibility for Higher Education institutions to be evaluated by international agencies and, in this area, reforms at national level are slow, since until the Bucharest Declaration (2012) only twelve countries of the European Higher Education Area have been integrated into ENQA. Portugal obtained full status as a member of ENQA in 2014.

\section{Lifelong Learning as a basis for the democratization of training}

In a world that develops at a faster rate, there is a recognition that it is absolutely necessary to develop skills continuously and permanently throughout life. Knowledge is seen as a transmutable, continuous and forever unfinished basis, placing education and training in the face of great challenges, which go through the preparation of the new generations to orient themselves creatively in the face of this constant change. In this sense, the new concepts of education, training and learning go beyond a purely individual duty, to a broad global responsibility to all citizens. This question of interdependence develops new educational meanings, paving the way for issues such as solidarity, humanism 
and civility, being fundamental aspects for the survival of the individual in society. In this way, a concept of citizenship is born that holds the individual responsible for active participation and collective life, and the idea that usefulness will not only be what is appropriate to the individual as an individual, but above all what makes him / With the world around them, strengthening a truly participatory democracy.

Lifelong learning has become a fundamental need for the continuity of learning and training, ultimately contributing to the democratization of education. In this sense, it will be indispensable to assume a renewed spirit that leaves stereotypes of knowledge as exclusive patrimony of training institutions and that allows the dynamization of multiple hypotheses for its construction, proving fundamental for the achievement of ambitious strategic objectives driven by Bologna (Berlin Declaration, 2003; Bologna Declaration, 1999; Budapest-Vienna Declaration, 2010; Bucharest Declaration, 2012; Leuven Declaration, 2009; Magna Charter of European Universities, 1988; Prague Declaration, 2001).

Education and Training Monitor (European Commission, 2015) considers that one of the current challenges for member states will be to convince Higher Education institutions that acquired skills and qualifications are not relevant forever in a changing world, promoting lifelong learning, especially in the adult population. According to the same study, only about $10.7 \%$ of Europeans (between 25 and 64 years old) participate in training actions, down to $4.4 \%$ for those with lower levels of education. In addition to these results, the report on the impact of the Bologna Process states that while member states recognize the importance of lifelong learning in overcoming Europe's economic and financial crisis, it is not properly legislated in operational terms and insists on several obstacles, notably in terms of their funding (European Commission, EACEA \& 
Eurydice, 2015). Given the results presented, we can see that lifelong training, which provides adequate training for the public with a new, more diversified profile, has not yet materialized as desired. Today, Higher Education maintains a student reality of growing heterogeneity, which also has implications for the social dimension.

\section{Social dimension and the implementation of the democratization of higher education}

With the Bologna Process, there was an awareness among member states of the need to increase competitiveness by balancing it with the aim of improving the social characteristics of the European Higher Education Area. The aim is to strengthen cohesion and reduce social inequalities, both at national and European level. A joint effort has been made to democratize education and, consequently, the society manifested through the various meetings in the framework of the Bologna, and one of the most recent meetings in Yerevan (Yerevan Declaration, 2015) establishes as priorities the strengthening of critical and tolerant thinking, gender equality in access and attendance in higher education, the development of values democratic and civic values of European and world citizenship, the development of more inclusive societies, also referring to the fact that the economic conditions of the students can't condition the possibility of attending Higher Education.

On the consolidation of the social dimension within the framework of the Bologna Process, although some progress has been made, the latest studies show that the goal of providing equal opportunities in access to higher education is far from being achieved. In all countries, the children of uneducated people are less likely to attend Higher Education, despite the commitment made in the Leuven Declaration (2009), to set measurable targets 
to increase the frequency of the most disadvantaged groups by 2010 only seven countries in the European Higher Education Area do not charge students fees and there is a large difference in the value of scholarships awarded between the various participating countries (European Commission, EACEA \& Eurydice, 2015).

From the analysis previously outlined to the challenges and opportunities brought about by the Bologna Process, we can highlight two aspects: firstly, it is clear that despite the fact that a recognized advance in the pursuit of Bologna's assumptions and consensus the need for its consolidation, its complete implementation is still a challenge to be achieved; a second aspect, refers to the fact that in all of the assumptions we have previously analyzed and which we consider to be the most relevant in Bologna, they are all found in the fundamental reflection of our work, which focuses on the importance attributed to the meaning of competence and its acquisition, in particular from generic to specific, thematic that we will develop next, namely analyzing its impact on the Portuguese Higher Education system.

\subsection{Teaching centered on the acquisition of competences within the framework of the Bologna Process}

The central issue in the Bologna Process is the "paradigm shift from a passive model, based on the acquisition of knowledge, to a model based on the development of competences" (DL $\mathrm{n}^{0} 74 / 2006$, Preamble). In order to achieve the aforementioned objective, combined with the idea of an investment of Higher Education in the formation of human capital, it will be necessary to integrate the knowledge acquired by the training with the knowledge required by society in general and by employers in particular. The competences set forth in the educational programs 
must therefore take into account the graduates exit profile after completing a course of study.

In spite of the above-mentioned need, according to a study carried out under the Tuning Project, we can verify that, in the context of European Higher Education, curricula and their development process demonstrate that the skills required are (González \& Wagenaar, 2008), which hindered the continuation of the strategic measures adopted and demonstrated the persistent resistance to the profound reform that is intended implement in Higher Education.

In the context of globalization, and faced with the challenges arising from the underlying competitiveness, competencies have gained prominence in relation to the teaching objectives. The objectives were, so far, set as goals to be achieved by the student through his training. Competence reinforced "the meritocratic character of our societies and accelerate the appeal to individual mechanisms of social mobility" (Fernandes, 1998, as quoted in Azevedo, 2007, p. 23), thus developing a culture that revolves around the most competent are those who obtain the best jobs and, in the limit, that the competent ones are those who obtain employment (Azevedo, 2007).

The conceptual debate in Portugal around the terms objective, competence and knowledge has been taking shape in the last years, evidenced, first, by a discourse marked by the valorization of the organization of the teaching and learning process around the acquisition of competences, namely in the Basic Education with the publication of the National Curriculum of Essential Skills (Ministry of Education, 2001), and in Higher Education with the Bologna Process. However, this idea is later refuted by Office no. 17169/2011, which repeals the aforementioned document for Basic Education, and by Law-Decree no. 115/2013, which questions the notion of competence given by the previous decree for Higher 
Education. That is to say, in Portugal we are witnessing, at the present moment, a certain contradiction of the legislation in force with respect to what has constituted the central motto of the current higher education with the Bologna Process. In our opinion, these advances and legal recalls have made it impossible to understand the importance of the acquisition of competences by the various actors and the consequent implementation in the portuguese Higher Education system of an agreement of supranational commitment, and to reflect on their concepts.

The attainment of a particular educational goal presupposes that a student learns a content or knowledge in a given teaching and learning situation. The acquisition of a certain competence is verified, in turn, when the student, before a given situation, is able to adequately mobilize different prior knowledge, selecting them and integrating them in a certain practical situation (Roldão, 2003).

The verbs associated with these two concepts (achieving goals and acquiring competences), although they have the same meaning in the written expression, refer us to different meanings. While achieving something evidence to be achieved in the future, something to be achieved, the acquisition, in turn, sends us to something achieved, as a condition required to complete a certain training. In other words, while the term objective refers to the type of knowledge that the student must achieve, personalizing a certain staticism in relation to the knowledge to be achieved in the theoretical scope, competence, on the other hand, presupposes a transposition of the knowledge reached for the practice of demonstrating a certain performative dynamism. It should be noted that competence does not neglect the value of knowledge, but adds to this static knowledge a dynamic that enables the student to adequately mobilize different prior knowledge, selecting them, integrating them and adjusting them 
to a particular activity. That is, competence implies mastery of content knowledge as a fundamental prerequisite, but with the added value of properly contextualizing it to practical situations, an idea that is closer to real professional needs.

Within the current context of formation, the simple static, disintegrated and decontextualized reach of knowledge is no longer sufficient, if one does not know how to integrate this knowledge in a given dynamic context of professional action. What is at stake here is therefore the abolition of a mode of learning based on the student's passive acquisition of certain knowledge. We want to implement a practical application of knowledge in the various contexts of working life, thus making the connection of this knowledge with previous life experiences, building an effective integration between knowledge, scientific innovation and actual professional practice.

In the context of higher education, the concept of competence is often associated with a broader and generic notion, such as ability or strategy, although these terms have different meanings from the previous one (Simão, 2002). Effectively, the term capacity refers to a given set of generic provisions which, once developed through contact with a particular cultural context, will give rise to the acquisition of several individual competences. In this sense, while "competence is seen as an inner potentiality [...] capable of generating a multitude of behaviors" (Simão, 2002, p. 21), assuming itself as the attested capacity to employ knowledge, skills and Social and / or methodological skills in occupational situations or in study contexts and for the purpose of professional and / or personal development (European Commission, 2006, December 18); capacity, in turn, is part of the process of acquiring competencies, in order to become more or less competent, depending on the possibilities and opportunities we will have to develop them at the practical level (Simão, 2002). 
As regards the distinction between competence and strategy, while the term competence is revealed through the manifestation of behaviors, that is to say through the application of certain procedures in a conscious way, in the case of knowledge acquired in a more profound and consolidated form, the strategy requires A conscious and rational response to reach an end (Simão, 2002). The strategy will be linked to a form of application of skills already acquired. In short, both the capacity and the strategy integrate the development of a given competency, the first being directly related to its acquisition and the second with the form to be achieved.

Along with the idea of competence, the idea of learning outcomes has begun to emerge in Higher Education, with the same meaning, referring to the "statement of what a learner knows, understands and is able to do when the learning process is completed learning" (European Commission, 2006, December 18, p. 3). That is, the learning outcomes refer to the minimum knowledge, skills and competences for obtaining credits.

Within the scope of the Tuning Project, a project on the benchmarking of the kind of competencies evidenced as fundamental by the participating European institutions was developed, a kind of preliminary project was carried out at the European level, in consultation with employers, graduates and teachers, in order to identify the generic competences that should be taken into account in the implementation of any study plan. Two major groups of competences emerge: specific competences, which relate to the type of particular knowledge related to a certain area of knowledge, and the generic or transferable competences, more directed to know how to be and know how to become (Lebrun, 2008), in order to prepare students for their future role in society, both in terms of employability and citizenship (González \& Wagenaar, 2008). 
These generic or transversal competences were, in turn, subdivided into three types: instrumental skills, which relate to cognitive, methodological, technological and linguistic skills; Interpersonal skills, which are related to individual capacities for personal, social and cooperation interaction; And systemic competencies, which refer to a holistic approach to knowledge, requiring their interrelationship with a more global perception of the processes of managing the same knowledge (González \& Wagenaar, 2008). In Portugal, through the publication of Law decree no.74/2006, of March 24, the five groups of competences are shown as reference points for the reorganization of portuguese Higher Education and for the achievement of the objectives established by the Bologna Process, the importance of acquiring transversal competences alongside the specific ones was highlighted, with the publication of Law Decree no. 107/2008.

The results of the study carried out by the Tuning Project (González \& Wagenaar, 2008) demonstrated that although generic or transferable competences are considered by the thematic groups consulted, they are of great relevance for the qualification of future graduates, which corroborates results from a another study carried out by Marcel Lebrun (2008) in the same context, the results show that European Higher Education institutions also privilege specific competences to the detriment of generic or transferable competences. That is, knowledge (referring to memorized knowledge) still occupies a prominent place in the academic world relative to other types of knowledge; making the correspondence with the taxonomy of Bloom (1956), perpetuates a level of lower complexity of skills.

The continuous process of search and refinement of knowledge allows to develop competences in the scope of learning to learn, being this one of the most innovative aspects in the scope of 
Higher Education pedagogy and that promises to give letters regarding the desired change of educational paradigm. We understand, therefore, that learning to learn, when properly developed, will respond to essential aspects of professional preparation: it develops a sense of autonomy, arouses interest in lifelong learning, triggers critical, reflexive and creative sense, strengthens problem solving and familiarizes the student with the possibility of error, which is often the starting point for the consolidation and / or renewal of learning.

Learning to learn, rather than providing the reach of knowledge, is objectified in the process of this search, in the strategies and attitudes that the student finds to achieve it. Thus, the current educational and training objectives of Higher Education go through learning to think, through learning to learn, that is, through learning to be. This is not a new idea, since the 1990 attitude skills have been seen as priority areas in educational development (Sprinthall \& Sprinthall, 1993).

If we refer to the taxonomy of Benjamin Bloom (1956) educational goals for cognitive domain, and to convey it to the current formative goals of higher education, we can see some correlation. For Bloom (1956), the definition of what the student is expected to acquire as knowledge will be essential to ensure an adequate selection of the specific procedures or means of teaching to be implemented in the classroom. In this sense, Bloom (1956) presents six stages of educational objectives that equate to levels of increasing complexity: Basic Knowledge (level one) adjusts to the type of competencies of lower complexity level in which the students assimilate the information of form passive and little reflected, tending to dominate facts, concepts, terms, specific methods without questioning or pondering, appealing to the memorization and automation of knowledge; Understanding (level two) adds to the previous stage the need for 
students to understand what they have acquired as knowledge; The Application (level three) refers to the use of knowledge in real situations, with a view to integrating theoretical knowledge into practical knowledge; Analysis (level four) refers to a more advanced level two level (Understanding) and requires students to organize information into the various components and understand the relationships between them and the organizing principle; Objective Synthesis (level five) corresponds to learning to select the material and the most important ideas of the same, building a new theory beyond what is known, thus impelling new ways of understanding; Objective Assessment (level six) implies all previous levels and therefore corresponds to the highest degree of complexity, presupposing the creation of patterns of appreciation and their use in a reflected way.

Lebrun (2008) adds another one, in the scope of the knowledge extracted from the taxonomy of Bloom (1956), where high-level skills are classified by increasing degree of complexity: the know how to become. This knowledge, according to the author, corresponds to the stages Synthesizing and Evaluating and adds to the knowledge to be "a dynamic and temporal perspective" (p. 32), demonstrating how the individual projects to find his future, that is, the effort that prints to achieve your goals.

Being the knowingness and the knowledge to be interdependent of the other two knowledges, they are located in a higher level of competences, by the degree of personal and social complexity. Knowledge is intervened in the way the individual analyzes a given situation, according to his or her points of view and values, and the ones that he or she will withdraw according to their experience. Knowing becoming, in turn, intervenes in the way the individual evaluates his situation and evaluates himself with regard to the objectives or the project to which he has surrendered (Lebrun, 2008). It will be fundamental for higher 
education institutions to rethink and renew their practices in order to develop higher level skills in the teaching and learning process.

In view of the above, it is clear that knowledge is only valid if it is integrated into a dynamic context of action. That is, the students receive the knowledge with an attitude of true involvement in the achievements they achieve, thus looking for the integration of this knowledge in their lives and needs, awakening their critical sense, creativity in problem solving, the sense of responsibility and the readiness to learn, enabling them to learn throughout their lives. We refer, therefore, to the higher order skills, which we have explored previously in this study, which by the increasing degree of complexity have to do with knowing, knowing how to do and knowing how to be. According to the most recent results of the 2009 International Program for Students Assessment (PISA), Portuguese students have revealed their weaknesses in particular at the level of high level skills (understanding, interpreting, evaluating, reflecting). At the most elementary level, related to the type of questions that only require memorization and automation of knowledge, the Portuguese students revealed to be fit (Office of Educational Evaluation, 2010).

In the context of the new educational paradigm driven by the Bologna Process, the specific learning goals for Higher Education go through the development of several generic and transversal competences in students, an objective extended to all courses or areas of knowledge and provided for in Law-Decree no. 107/2008. These competences require the development of reflexive and critical thinking, implying the exercise of reasoning, the formulation of judgments, openness to new ways of thinking, autonomous action in diverse contexts, respect for the people around us, subordinate to the performance as a person under 
ethical principles and citizenship. They will also imply that the student is an active element in the learning process, developing the ability to know how to direct their own learning according to their professional interests and expectations (Garrison \& Archer, 2000).

\section{Methodology}

In the scope of our study, we intend to answer the following research question: What competences are valued in the course under study? In order to answer this question, it is intended to achieve the following objectives: to confront the legislation decreed at national level, the regulation decreed at institutional level with the actual practice of the courses under study and with the assumptions of Bologna; Know the meaning attributed to competence by the various actors and what kind of competence is most important for them; To identify the incidence of the type of competences in the programs of the curricular units under study.

Taking into account the objectives set forth for the present study, we chose to carry out a naturalistic and phenomenological study taking into account the context of the courses under study that was understood through the analysis of documents and through the experiences and personal opinions of the various stakeholders being closely linked to the experiential dimension of the study situation, as it is perceived and manifested through the language that comes from it (Fortin 2003; Lincoln \& Guba 1990; Patton 1990).

We carried out a comparative case study of a course taught in two Portuguese university and polytechnic higher education institutions, denominated by institution $\mathrm{A}$ and institution $\mathrm{B}$, respectively. We analyzed two particular cases of formation and 
proceeded to their subsequent description, understanding and comparison (Yin, 2003; VanWynsberghe \& Khan, 2007).

In the present research, we opted for the qualitative approach, since we studied two training contexts through the application of qualitative data collection techniques and data analysis techniques, namely semi-structured interviews with teachers and course coordinators (Ghiglione \& Matalon, 2001; Tuckman, 2002), focus groups to the students (Krueger \& Casey, 2009; Zuckerman-Parker \& Shank, 2008;), to a total of twenty-four subjects, and to the documentary analysis of institutional documents. The emerging data analysis technique used was the analysis of conventional and directed qualitative content (Hsieh \& Shannon, 2005; Mayring, 2000;).

\subsection{Presentation and Discussion of Results}

In the Regulations of the two institutions, the acquisition of competences is one of the presuppositions for the organization of teaching and learning of the courses, highlighting them as fundamental for a "high level" training. However, in the analyzed programs of institution A they are objective statements, denominating them "Specific Objectives of the Discipline", and a curricular unit does not clarify about the objectives or competences to be developed in the students, stating instead the contents to explore in the same. Aspects that, on the one hand, collide with what is institutionally regulated and with Bologna's presuppositions, and on the other hand, it is assumed that the student who knows what is expected of him at the learning level can develop an effort more accurate and adequate to achieve the expected results.

As regards the definition of the concept of competence, it is not defined in any document of the institutions under study. From 
the results obtained from the teachers interviewed in institution $\mathrm{A}$, they associated the concept of competence with a continuous process of development of know-how. However, this knowledge for teachers refers only to the ability of the student to transmit a certain concept, one of the teachers adding that competence and knowledge may not coexist, contrary to what we have explored in the theoretical framework. In institution B, there is no consensus on the definition of competence among teachers. If some are close to the concept associated with Bologna's assumptions, others distance themselves from it, relating it to economic issues, even demonstrating a reactive attitude towards their development. A teacher in the area of education said that the skills cannot be measured, as we questioned, since we do not understand, then, what is evaluated by the teacher. That is, although the acquisition of competences is one of the mottos of the Bologna Process, it is not understood in this way by the majority of the teachers participating in the study.

Although the acquisition of competences is one of the mottos of the Bologna Process, it is not understood by some teachers in this way. In our view, this aspect compromises the achievement of one of the most important objectives of Bologna. The students of institution A stated that the concept of competence is reductive because it does not cover all the aspects that relate to training. One of the students of institution $\mathrm{B}$, in turn, considers that competence has to do with the ability to apply knowledge in the execution of scientific work. In view of the above, we risk saying that in both institutions students are unaware of the true scope of the concept.

In the programs of institution $\mathrm{A}$, the tendency is for the formulation of objectives rather than competences, namely of specific competencies. Of the emerging generic competences, the most relevant are the instrumental ones, referring to the 
capacity of analysis, reflection and research. The following are interpersonal skills, such as critical ability, and systemic skills such as the ability to investigate. In institution $\mathrm{B}$, in curricular unit programs, the objectives are stated in a timely manner, but the specific competences to be acquired by the students prevail. However, the generic ones appear more frequently than in the other institution. As in A, the instrumental skills are the most referenced, such as the capacity for analysis, research and organization of information and mastery of basic knowledge for the exercise of the profession. In the instrumental ones, the critical capacity and mastery of the basic knowledge of the profession prevails. In systemic terms, the ability to apply in practice the acquired knowledge and the ability to open and adapt knowledge to different contexts prevails. There seems to be in this institution a better understanding of the concept of competence bound up by the Bologna Process.

Although in the programs of the two institutions the specific competences were highlighted, the type of competences mentioned by the professors interviewed as being the most valued were, curiously, the generic ones. The teachers of institution A mentioned that, given their complexity and the high number of students per class, they found many difficulties in the evaluation of these competences, so they assume not to use a formal evaluation instrument. The majority of the teachers of institution B stated that it evaluates the generic competences through the personalized support of the student in the execution of the work, and one teacher referred to resort to the definition of personalized criteria, meeting what is recommended by Bologna Process.

However, in the programs we have seen that the specific competencies are the most valued, since they present higher percentage weights than the generic ones. These results are 
in line with those obtained by the Tuning Project (González \& Wagennar, 2008) and Marcel Lebrun (2008), confirming that, although generic competences are considered by teachers of great relevance for the qualification of future graduates, specific competencies Are still privileged in practice. Corroborating with what was developed in the theoretical framework, knowledge still occupies a prominent place in the academic world relative to other types of knowledge. These results also collide with one of the objectives set forth in Decree-Law no. 107/2008, which calls for the effective development of generic competences in students.

\section{Final Comments}

The study demonstrates a certain lack of knowledge of the various players in relation to the main assumptions brought by Bologna Process, namely on the real scope of the meaning of competence and its potential for quality training, ignorance that can be extended to many other aspects. Interpretations on the Bologna Process collide and call into question the operationalization of its main premises. This was a difficulty recognized in the most recent meetings of the member states (Bucharest Declaration, 2012, Budapest-Vienna Declaration, 2010; Yerevan Declaration, 2015), where it was found that the proposals made by Bologna in many Countries were not correctly implemented, a call was made for a better understanding and global involvement of the various actors in Bologna's presuppositions, and the countries of the European Higher Education Area were called upon to commit their political leaders to the effective implementation of the Bologna in all its aspects. In fact, although there has been a commitment by Member States to the implementation of 
the Bologna Process in higher education systems, the policies implemented at national level are not always the most appropriate in achieving the objectives of harmonization and consolidation advocated in the framework of this Process, since this sense of convergence does not always rule the wills of political leaders, as it is seen in the conceptualization of the meaning of competence in Portugal.

In short, although the Bologna Process has had a huge impact on the European Higher Education Area, there is still a clear demonstration that this impact has been better achieved in its structural and administrative implementation than at the level of its practical implementation, Corroborating with Sampaio da Nóvoa (Queirós, 2009, April 28), who mentioned that in the Bologna Process there is a lot of "cosmetic" and little effective change, and this is surely an important reason for reflection by all stakeholders.

For Portugal, and for the great majority of European countries, the implementation of a system of credits translated into the acquisition of a set of competences considered essential for the achievement of quality in the professional performance of the citizens, implies in itself a profound change In the educational paradigms traditionally assumed by higher education institutions. This change brings, therefore, innovations in the structuring of the training courses, at the level of the roles now assumed by the teacher, in the teaching and assessment dynamics that provides, and by the student, in the learning dynamics that develops. It is necessary, therefore, to reformulate the whole organization and instructive action of Higher Education. This restructuring involves a consequent adaptation of the teaching, learning and evaluation methodologies for the acquisition of competences that, in the last instance, make possible a greater effectiveness in the professional responses to the labor market. 
The reflection that we have developed here intends to find in the critical points of the implementation of Bologna explored, ways of interpreting the needs arising from the complexity that the paradigm change imposes, constituting an important reason for reflection of the institutions of Higher Education, its leaders, teachers And students, since any transformation with this reach entails disorders of a different order, which only time can dispel with the commitment and participation of all those involved.

\section{References}

Azevedo, J. (2007). Sistema educativo mundial. Ensaio sobre a regulação transnacional de educação. Vila Nova de Gaia: Fundação Manuel Leão.

Barcelona Declaration (2002). Convention of European Ministers of Education meeting in Barcelona on $15^{\text {th }}$ to $16^{\text {th }}$ March 2002.

Berlim Declaration (2003). Convention of the European Ministers of Education meeting in Berlin on $19^{\text {th }}$ September 2003.

Bloom, B. (1956). Taxonomy of educational objectives, handbook 1: cognitive domain. Nova Iorque: Mckay.

Bolonha Declaration (1999). Convention of the European Ministers of Education meeting in Bologna on $19^{\text {th }}$ June 1999.

Bucharest Declaration (2012). Convention of the European Ministers of Education meeting in Bucharest on $26^{\text {th }}$ and $27^{\text {th }}$ April 2012.

Budapest-Vienna Declaration (2010). Convention of the European Ministers of Education meeting in Vienna on $10^{\text {th }}$ to $12^{\text {th }}$ March 2010.

Dréze, J., \& Debelle, E. (1983). Conceções da universidade. Fortaleza: Universidade Federal do Ceará.

Education Ministry (2001). Currículo nacional do ensino básico. Competências essenciais. Lisboa: Ministério da Educação.

European Commission (2006, december 18). Recomendações do parlamento europeu e do conselho relativas à instituição do quadro europeu de 
qualificações para a aprendizagem ao longo da vida. Jornal Oficial da União Europeia, 962/CE. Recovered in 2011, january $7^{\text {th }}$, to http://eur-lex. europa.eu/LexUriServ/LexUriServ.do?uri=OJ:L:2006:394:0010:0018:pt:PDF European Commission (2015). Education and Training Monitor 2015. Recovered in 2015, november 11th, to http://ec.europa.eu/education/library/publications/monitor15_en.pdf.

European Commission, EACEA, \& Eurydice (2015). The European Higher Education Area in 2015: Bologna Process. Implementation Report. Recovered in 2015 , october $7^{\text {th }}$ to http://www.cnedu.pt/pt/noticias/internacional/1015-relatorio-eurydice-the-european-higher-education-area-in-2015-bologna-process-implementation-report.

European Parliament and Council (2008, may 6th). Quadro europeu de qualificações para a aprendizagem ao longo da vida. Jornal Oficial C111. Recovered in 2010 , october $28^{\text {th }}$, to http://europa.eu/legislation_summaries/education_training_youth/lifelong_learning/c11104_pt.htm

Ferreira, N., Silva, S., \& Firmino, T. (2014, janeiro 18). Investigadores não sabem para onde vai a ciência portuguesa. O Público. Recovered in 2015, october $16^{\text {th }}$, to http://www.publico.pt/ciencia/noticia/ciencia-em-tempos-de-crise-1620237.

Feyo de Azevedo, S. (2004, november). Os novos paradigmas de formação no espaço do ensino superior e as actividades profissionais. Comunicação apresentada no Seminário - Reflexos da Declaração de Bolonha. Recovered in 2009, december $3^{\text {rd }}$, to http://paginas.fe.up.pt/ sfeyo/Docs_SFA_Publica_ Conferences/SFA_OP_20050601_Bolonha_Forum_CNPL.pdf

Fortin, M-F., (2003). O processo de investigação: da conceção à realização ( $3^{a}$ ed.). Loures: Lusociência (Original work in French, published in 1996). Garrison, D. R., \& Archer, W. (2000). A transactional perspective on teaching and learning: A framework for adult and higher education. Oxford: Pergamon. General Direction to Higher Education (2008). Estratégia de Lisboa. Recovered in 2010, may 12nd, to http://www.dges.mctes.pt/DGES/pt/ Reconhecimento/Uni\%C3\%A3o+Europeia/Estrat\%C3\%A9gia+Europa+2020/ Estrategia+Lisboa.htm 
Ghiglione, R., \& Matalon, B. (2001). O inquérito (4⿳⺈冂䒑 ed.). Lisboa: Celta Editora. González, J., \& Wagenaar, R. (Eds.) (2008). Tuning project. Universities contribution to the bologna process. An introduction. Recovered in 2010, march $30^{\text {th }}$, to http://www.unideusto.org/tuningeu/images/stories/Publications/ ENGLISH_BROCHURE_FOR_WEBSITE.pdf

Helsinki Seminar: Seminar on the Degree of Degree of the European Ministers of Education meeting in Helsinki on $16^{\text {th }}$ and $17^{\text {th }}$ February 2001.

Hsieh, H-F., \& Shannon, S. C. (2005). Three approaches to qualitative content analysis. Recovered in 2011, november $26^{\text {th }}$, to http://qhr.sagepub.com/ content/15/9/1277.full.pdf.html

Krueger, R., \& Casey, M. (2009). Focus group: a practical guide for applied research ( $4^{\text {a }}$ ed.). Thousand Oaks, Califórnia: Sage Publications.

Law-Decree no.107/2008, 25th de june. Importance of the acquisition of transversal competences in higher education.

Law-Decree no.115/2013, 7 th august. Stipulation of teaching staff requirements to teach in Higher Education.

Law-Decree no.74/2006, $24^{\text {th }}$ de march. Regulation of the changes introduced by the LBSE regarding the new organization model of Higher Education.

Lebrun, M. (2008). Teorias e métodos pedagógicos para ensinar e aprender. Lisboa: Instituto Piaget (Original work in French published in 2002).

Leuven Declaration (2009). Convention of the European Ministers of Education meeting in Leuven on $28^{\text {th }}$ and $29^{\text {th }}$ May 2009.

Lincoln, Y. S., \& Guba, E. G. (1991). Naturalistic inquiry. Newbury Park, Califórnia: Sage Publications.

Magna Charter of European Universities (1988). Convention of the Rectors of European Universities meeting in Bologna on $18^{\text {th }}$ September 1988.

Mayring, P. (2000). Qualitative content analysis. Forum: Qualitative Social Research, vol. 1, número 2. Recovered in 2011, november $24^{\text {th }}$, to http:// www.qualitative-research.net/index.php/fqs/article/view/1089

Neave, G. (1998). Modelos de éxito. Los sistemas de cuatro países han influído en la educación superior del mundo entero? Qué han aportado? Recovered 
in 2010 , march $29^{\text {th }}$, to http://www.unesco.org/courier/1998_09/sp/dossier/txt12.htm.

Office no.17169/2011, 23rd december. Revocation of Skills in Basic Education. Office of Educational Evaluation (2010). PISA 2009. Competências dos alunos portugueses. Síntese de resultados. Recovered in 2011 , may $20^{\text {th }}$, to http://www.gave.min-edu.pt/np3content/?newsId=346\&fileName=Sintese_Resultados_PISA2009.pdf

Patton, M. Q. (1990). Qualitative evaluation and research methods. Newbury Park, Califórnia: Sage Publications.

Prague Declaration (2001). Convention of the European Ministers of Education meeting in Prague on $19^{\text {th }}$ May 2001.

Queirós, M. (2009, april 28th). Ensino superior devia voltar ao ministério da educação. Diário Económico. Recovered in 2011, march $11^{\text {th }}$, to http:// economico.sapo.pt/noticias/ensino-superior-deveria-voltar-ao-ministerio-da-educacao_9097.html

Roldão, M. C. (2003). Gestão do currículo e avaliação de competências. Lisboa: Editorial Presença.

Salamanca Declaration (2001). Convention of the European Ministers of Education meeting in Salamanca on $29^{\text {th }}$ and $30^{\text {th }}$ March 2001.

Simão, A. M. V. (2002). Aprendizagem estratégica. Uma aposta na auto-regulação. Lisboa, Ministério da Educação: Autor.

Sobrinho, J. D. (2005). Educação superior, globalização e democratização. Qual universidade? Revista Brasileira de Educação, Brasil, 28. Recovered in 2010 , may $23^{\text {rd }}$, to http://www.scielo.br/scielo.php?pid=S1413-24782005000100014\&script=sci_arttext.

Sorbonne Declaration (1998). Convention of the European Ministers of Education meeting in Sorbonne on $25^{\text {th }}$ May 1998.

Sprinthall, N. A., \& Sprinthall, R. C. (1993). Psicologia educacional. Lisboa: McGraw-Hill (Trabalho original em inglês, publicado em 1990).

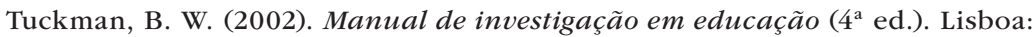
Fundação Calouste Gulbenkian (Original work in English, published in 1994). 
VanWynsberghe, R., \& Khan, S. (2007). Redefining case study. International Journal of Qualitative Methods, 6(2). Recovered in 2010, june $2^{\text {nd }}$, to http:// www.ualberta.ca/ iiqm/backissues/6_2/vanwynsberghe.htm

Yerevan Declaration (2015). Convention of European Ministers of Education meeting in Romania on $14^{\text {th }}$ to $15^{\text {th }}$ May 2015.

Yin, R. K. (2003). Case study research: design and methods ( $3^{\mathrm{a}}$ ed.). Thousand Oaks, Califórnia: Sage Publications.

Zuckerman-Parker, M., \& Shank, G. (2008). The town hall focus group: a new format for qualitative research methods. The Qualitative Report, 13, 630635. Recovered in 2011 , december $4^{\text {th }}$, to http://www.nova.edu/ssss/QR/ QR13-4/zuckerman-parker.pdf 